\title{
Foliar anatomical studies of some selected species of Dendrobium Sw. (Orchidaceae) in Manipur, India
}

\author{
Hidangmayum Bishwajit Sharma and Debjyoti Bhattacharyya ${ }^{1}$ \\ Department of Life Science \& Bioinformatics, Assam University, Silchar 788 011. Assam, India \\ ${ }^{1}$ Corresponding author: dbhattacharyya_aus@yahoo.in / debjyoti_bsi@yahoo.co.in \\ [Received 30.05.2019; Revised 24.06.2019; Accepted 25.06.2019; Published 30.06.2019]
}

\begin{abstract}
With an aim to understand adaptive significance and also to provide supplementary anatomical characters in addition to usual morphological features for identification of taxa at species level, foliar anatomical studies was carried out in 12 species of Dendrobium Sw. (Orchidaceae) from Manipur, India.

Structure and distribution of epidermal and hypodermal layers, stomatal type and density, mesophyll cells, wax secreting cells, trichomes etc. were studied in the present investigation. A key based on foliar anatomical characters is provided to ease the identification of species at vegetative stage.
\end{abstract}

Key words: Dendrobium, Epidendroideae, Leaf anatomy, North-east India, Orchid

\section{INTRODUCTION}

Dendrobium Sw. (Orchidaceae, Epidendroideae), an orchid genus of mostly epiphytic species, comprises nearly 3038 species (Govaerts et al. 2018) in the world. Most of the species of this genus are distributed in Sino-Himalayan region, Australia, New Zealand and Pacific Islands (Wood 2006). Some species are lithophytic too. The genus is represented by ca. 115 species in India (Misra 2007), of which, about 80 species are found in north-eastern part (Rao 2007; Chowdhery 2009). The north-eastern state Manipur harbours about 58 species as reported by some recent workers viz. Kumar \& Kumar (2005), Nanda et al. (2012, 2013, 2014), Kishor et al. (2013), Meitei et al. (2014) and Khuraijam \& Roy (2016). They generally grow in varied eco-climatic conditions ranging from tropical to sub-alpine habitats and are characterized in having globose or fleshy cane like stems with one or many, scattered or apically clustered leaves. The leaves vary in size, colour and texture; some are thick, fleshy and almost succulent with curious shapes. In many species, the leaves are short-lived and deciduous and shed off as soon as the dry season approaches. In others, leaves last for many years, even throughout the life of the plant.

As, the leaves are responsive to the environmental changes, they act as key characters in evaluating the effect of the environment on the plant and as well as to point out its adaptations to the environment (Dunbar et al. 2009). Anatomical formations of leaf are the basis of its physiological functions. The changes in leaf anatomical structures greatly affect plant growth and metabolisms (Vendramini et al. 2002; Pandey et al. 2009). Several anatomical features like stomatal furrows, sunken stomata, epidermal cuticles, etc. are commonly considered as adaptations to water scarcity; all these structures enhance boundary layer resistance, thereby limiting transpiration (Haworth \& McElwain 2008; Mill \& Stark 2009). Many foliar anatomical 
attributes have also contributed character information for phylogenetic classifications of orchids (Dressler \& Dodson 1960; Garay 1960, 1972a; Vermeulen 1966; Brieger et al. 1970-1995; Dressler 1981, 1993; Rasmussen 1985; Burns-Balogh \& Funk 1986; Szlachetko 1995; Freudenstein et al. 1999).

This paper deals with foliar anatomy of twelve species of Dendrobium from different eco-climatic conditions of Manipur, India. The aims of the study were to find out the important anatomical characters for identification of taxa at species level as well as to understand their adaptive significance.

\section{MATERIALS AND METHODS}

12 species of Dendrobium Sw. (Table 1) were taken into consideration for the present study. These were collected from various eco-climatic regions of Manipur, India. For leaf anatomical studies, thin cross sections through the middle portion of matured leaves of each species were done by a sharp razor blade and stained with safranine (Guan et al. 2010). Stained sections were examined under compound microscope (Olympus CX31) at different magnifications.

Table 1. List of species under study with their distribution (in Manipur), habitat and macromorphological vegetative characteristics

\begin{tabular}{|c|c|c|c|c|c|c|}
\hline Species & $\begin{array}{l}\text { Distribution } \\
\text { in the State } \\
\text { (Districts) }\end{array}$ & $\begin{array}{l}\text { Altitude } \\
\text { (m) }\end{array}$ & Habitat & $\begin{array}{l}\text { Stem size } \\
\text { [length }(\mathrm{L}), \\
\text { diameter(D) } \\
](\mathrm{cm})\end{array}$ & $\begin{array}{l}\text { Number } \\
\text { of leaves } \\
\text { on stem }\end{array}$ & $\begin{array}{l}\text { Leaf size } \\
{[\text { length }(L),} \\
\text { width(W)] } \\
(\mathrm{cm})\end{array}$ \\
\hline $\begin{array}{l}\text { Dendrobium } \\
\text { chrysotoxum } \\
\text { Lindl. }\end{array}$ & $\begin{array}{l}\text { Chandel \& } \\
\text { Senapati }\end{array}$ & $500-1800$ & $\begin{array}{l}\text { Tropical- } \\
\text { Sub- } \\
\text { tropical }\end{array}$ & $\begin{array}{l}\text { L: } 15-19 \\
\text { D: } 01-02\end{array}$ & $04-06$ & $\begin{array}{l}\text { L: } 12-15 \\
\text { W: } 3.0-4.5\end{array}$ \\
\hline $\begin{array}{l}\text { Dendrobium } \\
\text { densiflorum } \\
\text { Lindl. }\end{array}$ & $\begin{array}{l}\text { Senapati, } \\
\text { Tamenglong } \\
\text { \& Kamjong }\end{array}$ & $\begin{array}{l}1300- \\
2000\end{array}$ & $\begin{array}{l}\text { Sub- } \\
\text { tropical }\end{array}$ & $\begin{array}{l}\text { L: } 25-30 \\
\text { D: } 01-02\end{array}$ & $04-06$ & $\begin{array}{l}\text { L: } 13-17 \\
\text { W: } 3.0-4.5\end{array}$ \\
\hline $\begin{array}{l}\text { Dendrobium } \\
\text { falconeri Hook. }\end{array}$ & $\begin{array}{l}\text { Senapati \& } \\
\text { Tengnoupal }\end{array}$ & $600-2000$ & $\begin{array}{l}\text { Tropical } \\
\text { - Sub- } \\
\text { tropical }\end{array}$ & $\begin{array}{l}\text { L: } 35-40 \\
\text { D: } 0.2-0.4\end{array}$ & $20-25$ & $\begin{array}{l}\text { L: } 5-6.4 \\
W: 0.2-0.4\end{array}$ \\
\hline $\begin{array}{l}\text { Dendrobium } \\
\text { fimbriatum } \\
\text { Hook. }\end{array}$ & $\begin{array}{l}\text { Senapati \& } \\
\text { Tamenglong }\end{array}$ & $\begin{array}{l}1000- \\
1660\end{array}$ & $\begin{array}{l}\text { Sub- } \\
\text { Tropical }\end{array}$ & $\begin{array}{l}\text { L: } 60-90 \\
\text { D: } 0.9-1.2\end{array}$ & $20-30$ & $\begin{array}{l}\text { L: } 12-14 \\
\text { W: } 1.5-2.5\end{array}$ \\
\hline $\begin{array}{l}\text { Dendrobium } \\
\text { infundibulum } \\
\text { Lindl. }\end{array}$ & Tengnoupal & $400-1434$ & $\begin{array}{l}\text { Tropical } \\
\text { - Sub- } \\
\text { tropical } \\
\end{array}$ & $\begin{array}{l}\text { L: } 30-40 \\
\text { D: } 0.6-0.8\end{array}$ & $12-17$ & $\begin{array}{l}\text { L: } 10-12 \\
W: 2.0-2.5\end{array}$ \\
\hline $\begin{array}{l}\text { Dendrobium } \\
\text { jenkinsii Wall. } \\
\text { ex Lindl. }\end{array}$ & $\begin{array}{l}\text { Senapati, } \\
\text { Tengnoupal \& } \\
\text { Jiribam }\end{array}$ & $60-1400$ & \begin{tabular}{l|} 
Tropical \\
- Sub \\
Tropical \\
\end{tabular} & $\begin{array}{l}\text { L: } 2.0-2.5 \\
\text { D: } 0.5-0.7\end{array}$ & 01 & $\begin{array}{l}\text { L: } 3.5-4.2 \\
W: 1.5-2.0\end{array}$ \\
\hline $\begin{array}{l}\text { Dendrobium } \\
\text { longicornu } \\
\text { Lindl. }\end{array}$ & Senapati & $\begin{array}{l}1330- \\
3000\end{array}$ & $\begin{array}{l}\text { Sub- } \\
\text { tropical - } \\
\text { Temperate }\end{array}$ & $\begin{array}{l}\text { L: } 6-10 \\
\text { D: } 0.2-0.3\end{array}$ & $07-10$ & $\begin{array}{l}\text { L: } 4.0-5.5 \\
W: 0.8-1.1\end{array}$ \\
\hline $\begin{array}{l}\text { Dendrobium } \\
\text { ochreatum } \\
\text { Lindl. }\end{array}$ & $\begin{array}{l}\text { Jiribam, } \\
\text { Churchandpur } \\
\text { \& Senapati }\end{array}$ & $50-1800$ & \begin{tabular}{l|} 
Tropical \\
- Sub- \\
tropical
\end{tabular} & $\begin{array}{l}\text { L: } 20-38 \\
\text { D: } 1.0-1.3\end{array}$ & $08-16$ & $\begin{array}{l}\text { L: } 9-11 \\
W: 3.0-3.9\end{array}$ \\
\hline $\begin{array}{l}\text { Dendrobium } \\
\text { parcum } \text { Rchb.f. }\end{array}$ & $\begin{array}{l}\text { Kangpokpi } \\
\text { (the then } \\
\text { Senapati) \& } \\
\text { Tamenglong }\end{array}$ & $\begin{array}{l}1200- \\
1660\end{array}$ & $\begin{array}{l}\text { Sub- } \\
\text { tropical }\end{array}$ & $\begin{array}{l}\text { L: } 20-24 \\
\text { D: } 0.3-0.5\end{array}$ & $05-08$ & $\begin{array}{l}\text { L: } 4-5 \\
W: 1.0-1.3\end{array}$ \\
\hline
\end{tabular}


110 Foliar anatomy of Dendrobium Sw, from Manipur
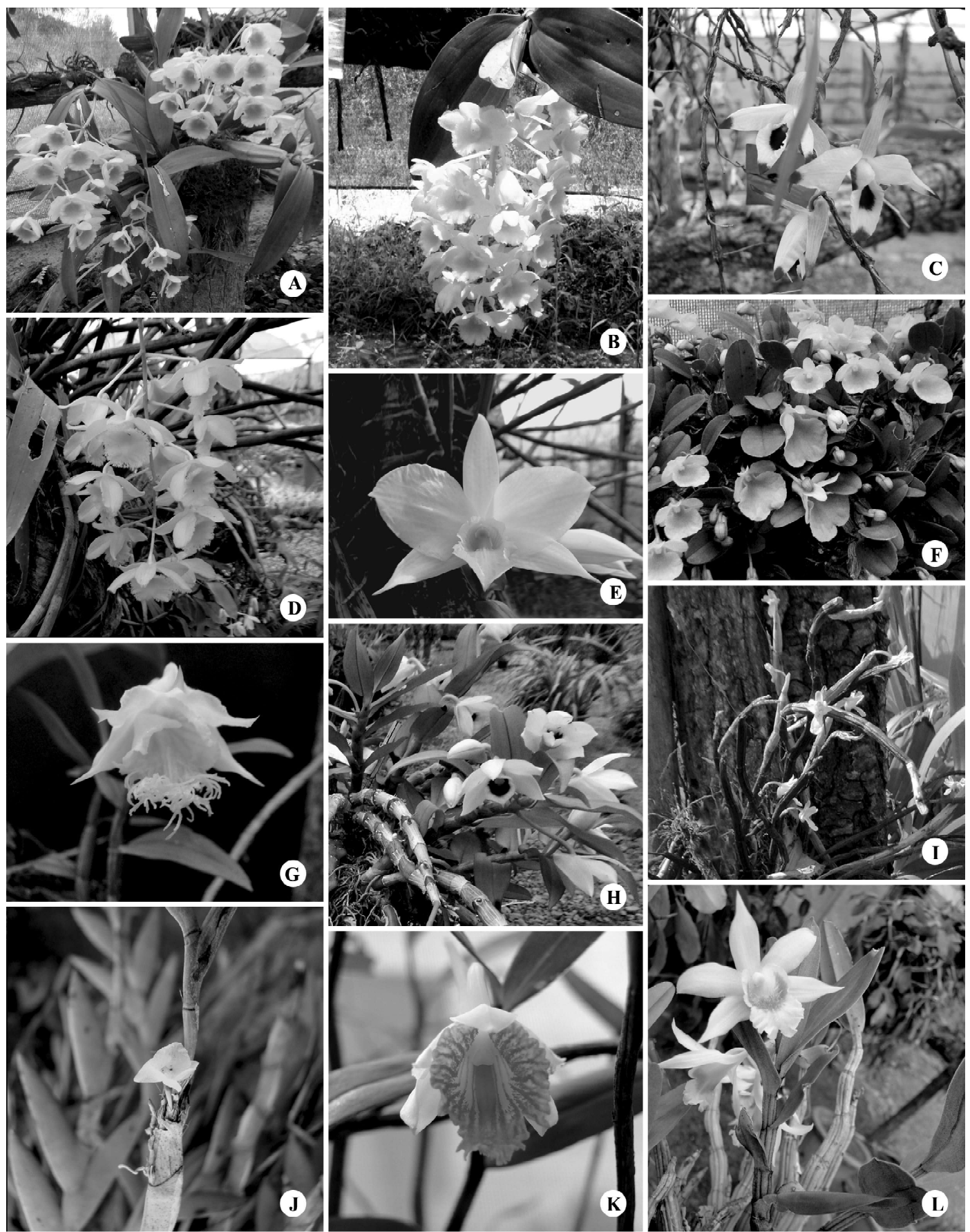

Figure 1. Habit of different species of Dendrobium. a. D. chrysotoxum, b. D. densiflorum, c. D. falconeri, d. D. fimbriatum, e. D. infundibulum, f. D. jenkinsii, g. D. longicornu, , h. D. ochreatum, $\boldsymbol{i}$. D. parcum, $\boldsymbol{j}$. D. spatella, $\boldsymbol{k}$. D. tamenglongense and $\boldsymbol{l}$. D. williamsonii 


\begin{tabular}{|c|c|c|c|c|c|c|}
\hline Species & $\begin{array}{l}\text { Distribution } \\
\text { in the State } \\
\text { (Districts) }\end{array}$ & $\begin{array}{l}\text { Altitude } \\
\text { (m) }\end{array}$ & Habitat & $\begin{array}{l}\text { Stem size } \\
\text { [length(L), } \\
\text { diameter(D) } \\
](\mathrm{cm})\end{array}$ & $\begin{array}{l}\text { Number } \\
\text { of leaves } \\
\text { on stem }\end{array}$ & $\begin{array}{l}\text { Leaf size } \\
\text { [length(L), } \\
\text { width(W)] } \\
(\mathrm{cm})\end{array}$ \\
\hline $\begin{array}{l}\text { Dendrobium } \\
\text { spatella } \text { Rchb.f. }\end{array}$ & Tamenglong & $\begin{array}{l}1000- \\
1800\end{array}$ & $\begin{array}{l}\text { Sub- } \\
\text { Tropical }\end{array}$ & $\begin{array}{l}\text { L: } 18-25 \\
\text { D: } 0.3-0.5\end{array}$ & $10-17$ & $\begin{array}{l}\text { L: } 3.0-3.5 \\
W: 0.8-1.3\end{array}$ \\
\hline $\begin{array}{l}\text { Dendrobium } \\
\text { tamenglongense } \\
\text { R. Kishor, Y. N. } \\
\text { Devi, H. B. } \\
\text { Sharma, J. } \\
\text { Tongbram \& S. } \\
\text { P. Vij } \\
\end{array}$ & $\begin{array}{l}\text { Tengnoupal } \\
\text { (the then } \\
\text { Chandel) }\end{array}$ & $400-1000$ & $\begin{array}{l}\text { Tropical } \\
\text { - Sub- } \\
\text { tropical }\end{array}$ & $\begin{array}{l}\text { L: } 60-75 \\
\text { D: } 0.3-0.5\end{array}$ & $15-20$ & $\begin{array}{l}\text { L: } 7-9 \\
\text { W: } 1.5-2.0\end{array}$ \\
\hline $\begin{array}{l}\text { Dendrobium } \\
\text { williamsonii } \\
\text { Day \& Rchb.f. }\end{array}$ & $\begin{array}{l}\text { Senapati, } \\
\text { Kangpokpi } \\
\text { (the then } \\
\text { Senapati) \& } \\
\text { Kamjong (the } \\
\text { then Ukhrul) }\end{array}$ & $\begin{array}{l}1300- \\
1800\end{array}$ & $\begin{array}{l}\text { Sub- } \\
\text { tropical }\end{array}$ & $\begin{array}{l}\text { L: } 13-16 \\
\text { D: } 0.5-0.7\end{array}$ & $07-10$ & $\begin{array}{l}\text { L: } 10-13 \\
W: 2.0-2.5\end{array}$ \\
\hline
\end{tabular}

To study trichomes, stomata, wax secreting cells etc., the adaxial and abaxial epidermis of fresh, matured leaves were peeled off. The area of stomatal apparatus was calculated following Guan et al. (2010) and the stomatal density was calculated following routine formula: Number of stomata/ Number of grids $\times$ area of 1 grid square. Character analyses for all the species were made following the method of Freudenstein and Rasmussen (1999) and results were presented as Mean \pm Standard Error $(\mathrm{M} \pm \mathrm{SE})$.

Character analysis (based upon coded characters):

A. First adaxial hypodermal layer: $0=$ absent, $1=$ present

B. Second adaxial hypodermal layer: $0=$ absent, $1=$ present

C. Abaxial hypodermal layer: $0=$ absent, $1=$ present

D. Mesophyll: $0=$ palisade and spongy not differentiated, $1=$ palisade and spongy slightly differentiated, 2 = palisade and spongy distinctly differentiated

E. Shape of middle vascular bundle: $0=$ globular, $1=$ ovate, $2=$ obovate, $3=$ elongated oval

F. Shape of adaxial leaf epidermal cells: $0=$ polygonal, $1=$ irregular or nearly polygon

G. Shape of abaxial leaf epidermal cells: $0=$ polygonal, $1=$ irregular or nearly polygon

H. Stomata: $0=$ anomocytic, $1=$ paracytic

I. Slightly sunken stomata: $0=$ absent, $1=$ present

J. Shape of guard cells: $0=$ elliptic, $1=$ sub-orbicular

K. Subsidiary cells: $0=$ present, $1=$ not distinguishable

L. Wax secreting cells: $0=$ absent, $1=$ present

M. Nature of adaxial wax secreting cells: $0=$ single, $1=$ double, $2=$ mixed, $3=$ not present

N. Nature of abaxial wax secreting cells: $0=$ single, $1=$ double, $2=$ mixed, $3=$ not present

O. Trichome: $0=$ absent, $1=$ present 
112 Foliar anatomy of Dendrobium Sw, from Manipur
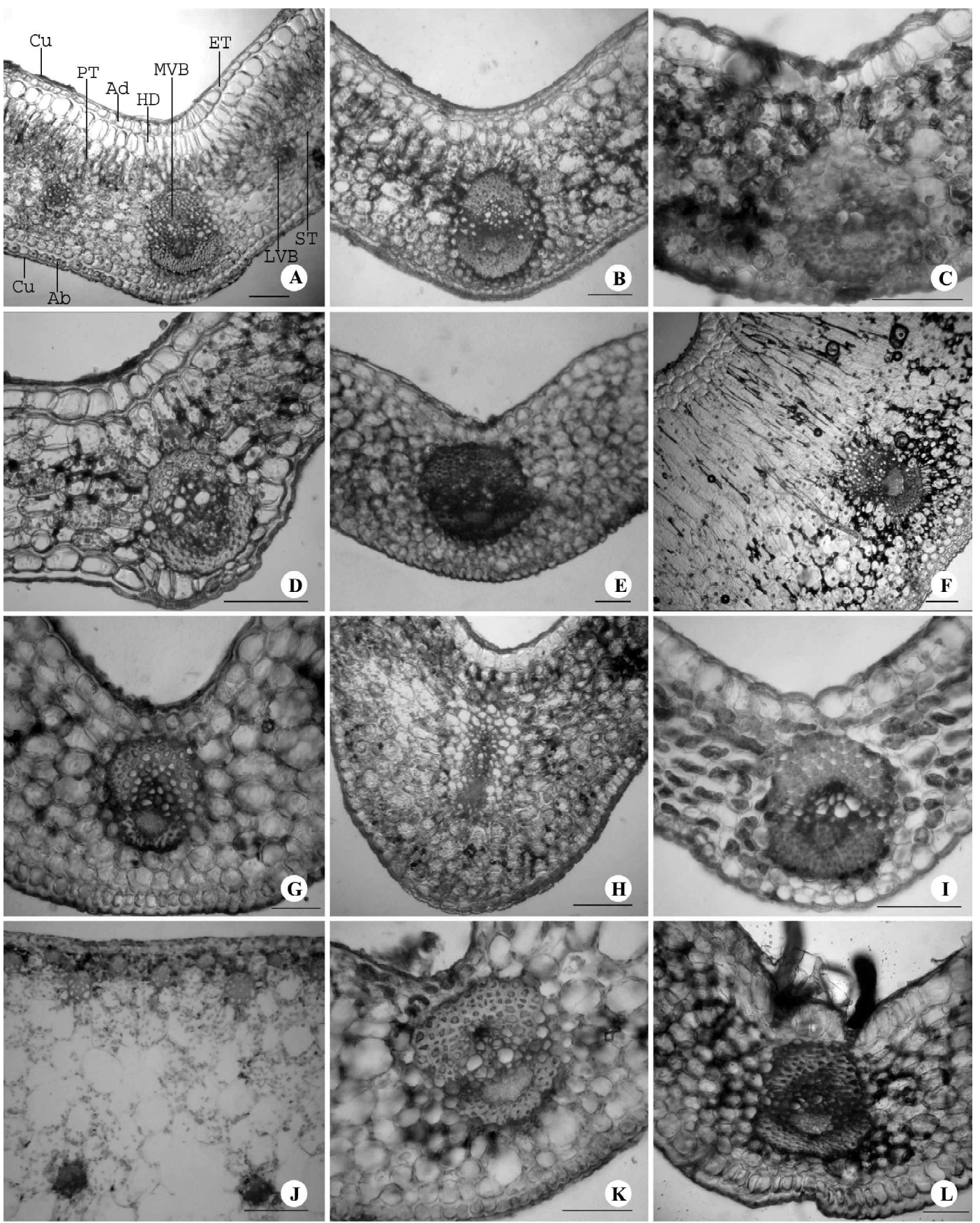

Figure 2. T.S. of Leaves. a. D. chrysotoxum, b. D. densiflorum, c. D. falconeri, d. D. fimbriatum, e. D. infundibulum, f. D. jenkinsii, g. D. longicornu, h. D. ochreatum, $\boldsymbol{i}$. D. parcum, $\boldsymbol{j}$. D. spatella, $\boldsymbol{k}$. D. tamenglongense and $\boldsymbol{l}$. D. williamsonii. Ab abaxial epidermis, Ad adaxial epidermis, Cu cuticle, ET epidermal tissue, HD hypodermis, LVB lateral vascular bundle, MVB middle vascular bundle, PT palisade tissue, ST spongy tissue. Scale bars, $500 \mu \mathrm{m}-\mathrm{j}, 100 \mu \mathrm{m}-(\mathrm{a}-i$ and $k-l)$. 


\section{RESULTS}

Observations made in the study are discussed below in detail under various headings along with data in tabular forms (Tables 2-4). Photographic plates are also given as Figures 1 4. A key based on foliar anatomy was also given to facilitate easy identification of species.

Cuticle: In all the species observed, cuticle was recorded on both the adaxial and abaxial surfaces. Cuticle of adaxial surface was found thicker than the abaxial surface in all the species except in D. parcum. D. infundibulum was recorded with the thickest adaxial cuticle layer $(16.50 \mu \mathrm{m})$ followed by $D$. williamsonii $(16.10 \mu \mathrm{m})$ and $D$. jenkinsii $(14.80 \mu \mathrm{m})$.

Epidermal layers: Epidermal cells were polygonal in all the species except in $D$. densiflorum where they are irregular to nearly polygonal (Figure $4 b$ ). Thickest adaxial epidermal layer was observed in D. ochreatum $(51.00 \mu \mathrm{m})$ and the thinnest in D. densiflorum $(20.40 \mu \mathrm{m})$, while thickest abaxial epidermal layer $(34.30 \mu \mathrm{m})$ was found in $D$. williamsonii and the thinnest $(06.50 \mu \mathrm{m})$ in $D$. falconeri.

Hypodermal layers: Out of the 12 species, only 2 species viz. D. chrysotoxum and $D$. jenkinsii showed the presence of hypodermis. Further, it was also observed that $D$. jenkinsii had two adaxial and one abaxial hypodermal layers (Figure $2 f$ ) while in $D$. chrysotoxum only one layer of hypodermis was found in both surfaces (Figure $2 a$ ).

Mesophyll layers: It has been observed that mesophyll layer is thickest in $D$. spatella $(8555.25 \mu \mathrm{m})$ and the minimum is in $D$. parcum $(145.00 \mu \mathrm{m})$. Mesophyll cells were clearly differentiated into palisade and spongy cells in D. jenkinsii (Figure $2 f$ ) and slightly differentiated in $D$. infundibulum (Figure $2 e$ ). Palisade cells have comparatively few numbers of chloroplasts than spongy cells.

Various shapes of vascular bundles were observed. In D. falconeri, D. infundibulum, $D$. parcum and $D$. spatella, the vascular bundles were globular in shape, whereas in $D$. chrysotoxum, $D$. densiflorum, $D$. fimbriatum and $D$. williamsonii, they were ovate. In $D$. jenkinsii and $D$. ochreatum, vascular bundles were elongated oval and in D. tamenglongense and $D$. longicornu they were obovate.

Stomata: In all the species, the stomata were observed only on lower surface (hypostomatic). In two species viz. D. spatella and $D$. williamsonii, the stomata were of paracytic type (Figure $3 j \& l$ ) and in rest of the species they were anomocytic. It is also interesting to note that only one species viz. D. ochreatum (Figure $3 h$ ) showed slightly sunken stomata. Stomatal density was maximum in D. chrysotoxum $\left(16.45 / \mathrm{mm}^{2}\right)$ and minimum in D. spatella $(02.82 /$ $\left.\mathrm{mm}^{2}\right)$. Further, the size of stomatal apparatus area $\left(\mathrm{A}_{\mathrm{s}}\right)$ was maximum in $D$. williamsonii $(1838.80 \mu \mathrm{m})$ and the minimum in D. jenkinsii $(639.90 \mu \mathrm{m})$.

The shape of the guard cell was elliptic in D. jenkinsii and D. parcum (Figure $3 f \& i$ ), whereas the remaining species showed guard cells are sub-orbicular. Presence of chloroplasts were also observed in all the species.

Wax secreting cells: Wax secreting cells on both adaxial and abaxial surfaces were observed in all the species except in $D$. infundibulim, D. longicornu and D. williamsonii which were observed with trichomes. The adaxial wax secreting cells were observed maximum in D. spatella $\left(53.00 / \mathrm{mm}^{2}\right)$ whereas minimum in D. parcum $\left(01.40 / \mathrm{mm}^{2}\right)$.

Trichomes: Unicellular dark brown trichomes were observed on both the surfaces of $D$. infundibulum, $D$. longicornu and $D$. williamsonii. The density of trichomes were found more on abaxial surface than the adaxial. The size of the trichome was longer in $D$. infundibulum (Figure 4-e). 
Table 2. Character analysis of 12 species of Dendrobium

\begin{tabular}{|c|c|c|c|c|c|c|c|c|c|c|c|c|c|c|c|}
\hline \multirow[t]{2}{*}{ Species } & \multicolumn{15}{|c|}{ Characters } \\
\hline & $\mathbf{A}$ & B & C & D & $\mathbf{E}$ & $\mathbf{F}$ & G & $\mathbf{H}$ & I & $\mathbf{J}$ & $\mathbf{K}$ & $\mathbf{L}$ & $\mathbf{M}$ & $\mathbf{N}$ & $\mathbf{O}$ \\
\hline D. chrysotoxum & 1 & 0 & 1 & 0 & 1 & 0 & 0 & 0 & 0 & 1 & 1 & 1 & 2 & 0 & 0 \\
\hline D. densiflorum & 0 & 0 & 0 & 1 & 1 & 1 & 1 & 0 & 0 & 1 & 1 & 1 & 2 & 2 & 0 \\
\hline D. falconeri & 0 & 0 & 0 & 0 & 0 & 0 & 0 & 0 & 0 & 1 & 1 & 1 & 0 & 0 & 0 \\
\hline D. fimbriatum & 0 & 0 & 0 & 0 & 1 & 0 & 0 & 0 & 0 & 1 & 1 & 1 & 0 & 0 & 0 \\
\hline D. infundibulum & 0 & 0 & 0 & 0 & 0 & 0 & 0 & 0 & 0 & 1 & 1 & 0 & 3 & 3 & 1 \\
\hline D. jenkinsii & 1 & 1 & 1 & 2 & 3 & 0 & 0 & 0 & 0 & 0 & 1 & 1 & 0 & 0 & 0 \\
\hline D. longicornu & 0 & 0 & 0 & 0 & 2 & 0 & 0 & 0 & 0 & 1 & 1 & 0 & 3 & 3 & 1 \\
\hline D. ochreatum & 0 & 0 & 0 & 0 & 3 & 0 & 0 & 0 & 1 & 1 & 1 & 1 & 0 & 0 & 0 \\
\hline D. parcum & 0 & 0 & 0 & 0 & 0 & 0 & 0 & 0 & 0 & 0 & 1 & 1 & 0 & 0 & 0 \\
\hline D. spatella & 0 & 0 & 0 & 0 & 0 & 0 & 0 & 1 & 0 & 1 & 0 & 1 & 0 & 0 & 0 \\
\hline D. tamenglongense & 0 & 0 & 0 & 0 & 2 & 0 & 0 & 0 & 0 & 1 & 1 & 1 & 2 & 2 & 0 \\
\hline D. williamsonii & 0 & 0 & 0 & 0 & 1 & 0 & 0 & 1 & 0 & 1 & 0 & 0 & 3 & 3 & 1 \\
\hline
\end{tabular}

\section{Key to the identification of species}

1a.Mesophyll differentiated into palisade and spongy layers. ...................2

1b. Mesophyll not differentiated ...........................................................

2a. Hypodermis multilayered .......................................................... jenkinsii

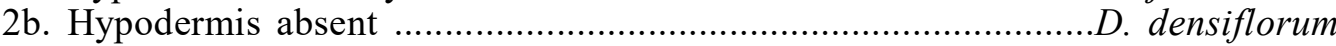

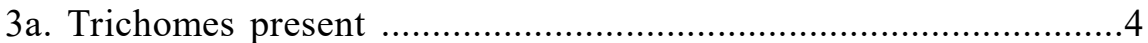

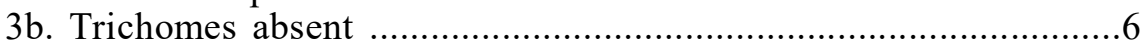

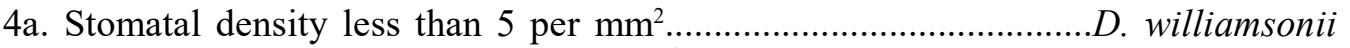

4b. Stomatal density more than 5 per $\mathrm{mm}^{2}$.........................................

5a. Central vascular bundle globular in shape .................................... infundibulum

5b. Central vascular bundle obovoid in shape ..................................... longicornu

6a. Stomata paracytic .................................................................. spatella

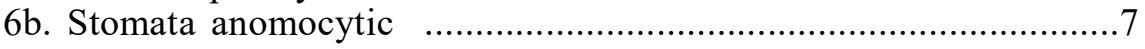

7a. Cuticle is thicker on abaxial surface ............................................ p. parcum

7b. Cuticle is thicker on adaxial surface ………................................ 8

8a. Hypodermis single layered on both the surfaces ............................ chrysotoxum

8b. Hypodermis absent ……..........................................................

9a. Density of wax secreting cells more than 25 per $\mathrm{mm}^{2}$ on adaxial surface..D. falconeri

$9 \mathrm{~b}$. Density of wax secreting cells less than 20 per $\mathrm{mm}^{2}$ on adaxial surface.. 10

10a. Stomata slightly sunken.

D. ochreatum

10b. Stomata not sunken 11

11a. Central vascular bundle ovoid in shape

D. fimbriatum

11b. Central vascular bundle obovoid in shape

D. tamenglongense

\section{DISCUSSION}

Adaxial cuticle was found thicker than the abaxial cuticle in all the species except in $D$. parcum. Characters like small size of the leaves, their position on the repeatedly branched stem which subject to frequent exposure of lower surface (abaxial) to the sunlight might have probably warranted the species $D$. parcum to develop thicker cuticle in abaxial surface 

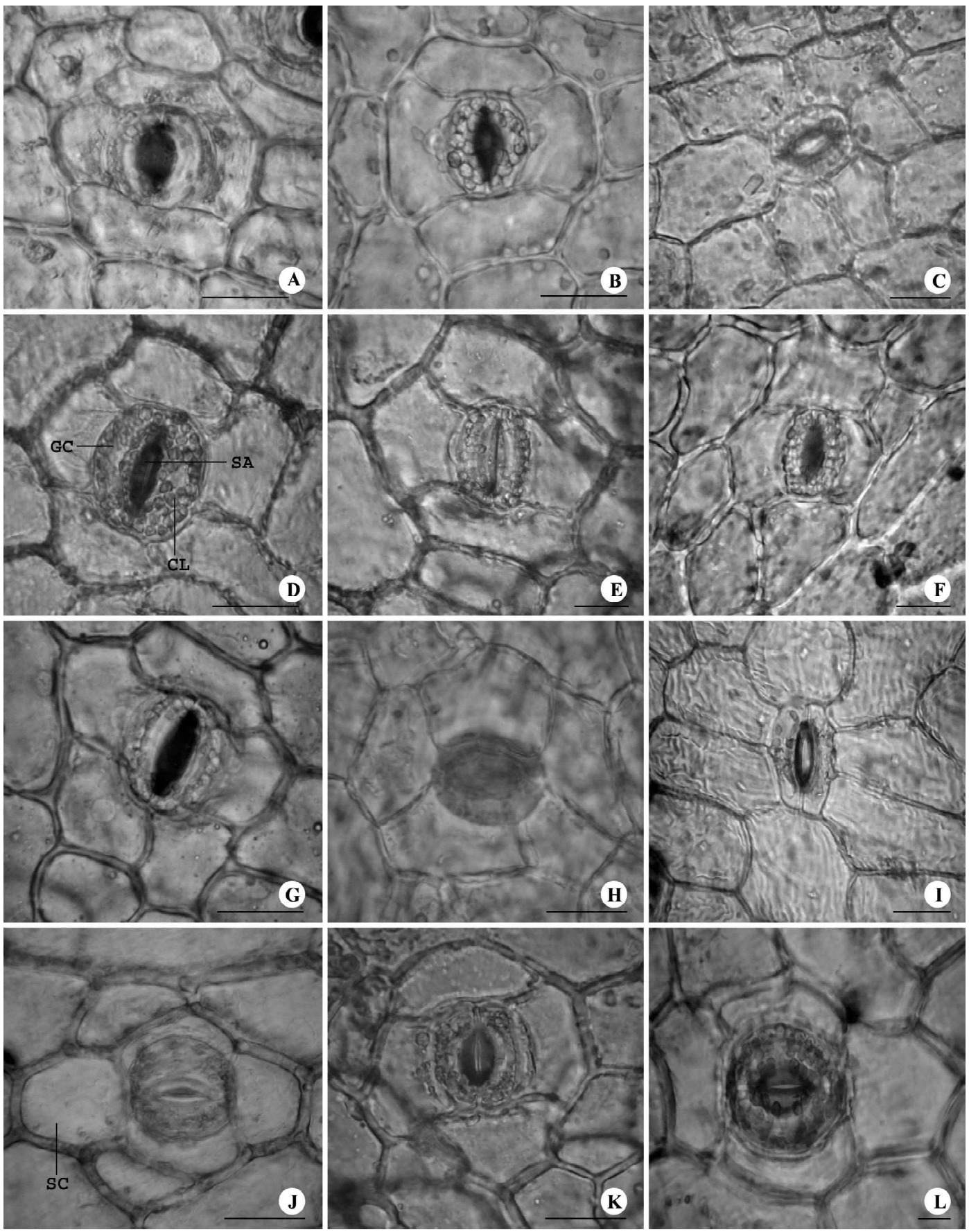

Figure 3. Stomata at abaxial leaf epidermis. a. D. chrysotoxum, b. D. densiflorum, $\boldsymbol{c}$. D. falconeri, d. D. fimbriatum, e. D. infundibulum, $\boldsymbol{f}$. D. jenkinsii, g. D. longicornu, $\boldsymbol{h}$. D. ochreatum, i. D. parcum, j. D. spatella, $\boldsymbol{k}$. D. tamenglongense and $\boldsymbol{l}$. D. williamsonii. CL chloroplast, GC guard cell, SC subsidiary, SA stomatal aperture. Scale bars, $30 \mu \mathrm{m}$ $(a-j), 100 \mu \mathrm{m}(k-l)$. 
116 Foliar anatomy of Dendrobium Sw, from Manipur

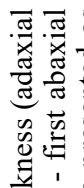

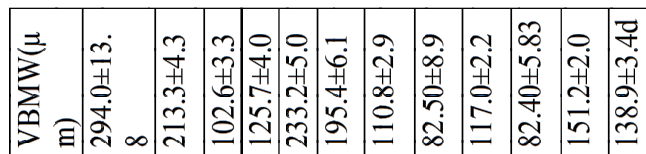

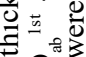

n目

过

중즈.

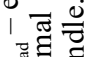

동

을

8

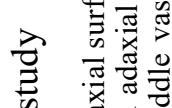

过

$\Xi$

o

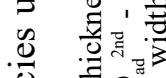

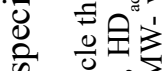

I

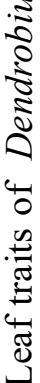

ย高产

琶

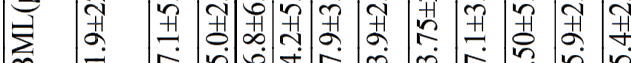

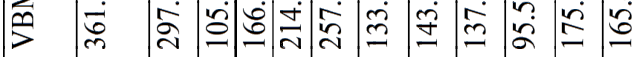

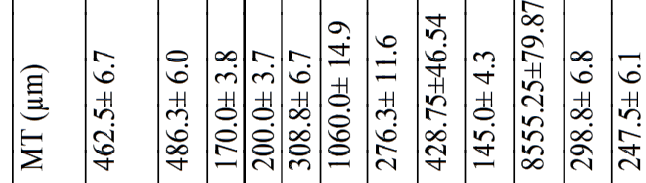

तิ

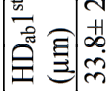

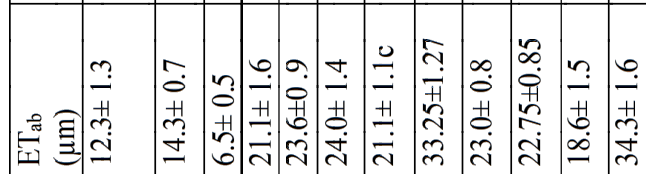

焗

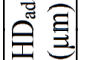

\%

苋这竞

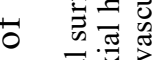

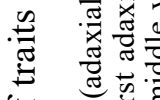

क

论,

등

$\frac{\pi}{\pi}$

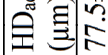

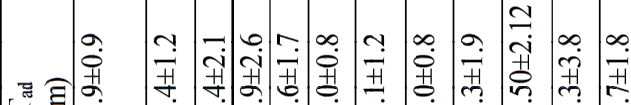

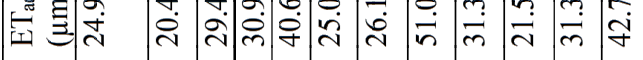

$\frac{0}{\frac{0}{\sigma}}$

告

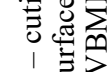

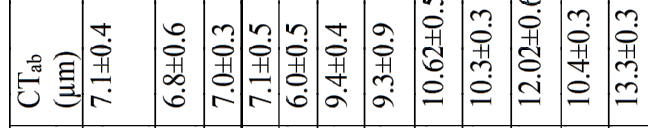

ज的

. $\frac{\pi}{x}$

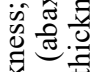

.

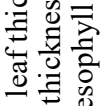

号

它豆

흥

今

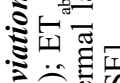

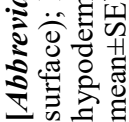

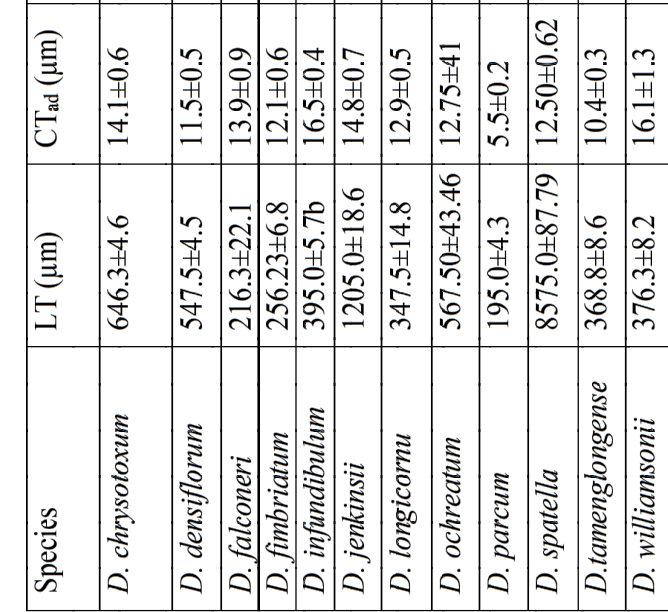



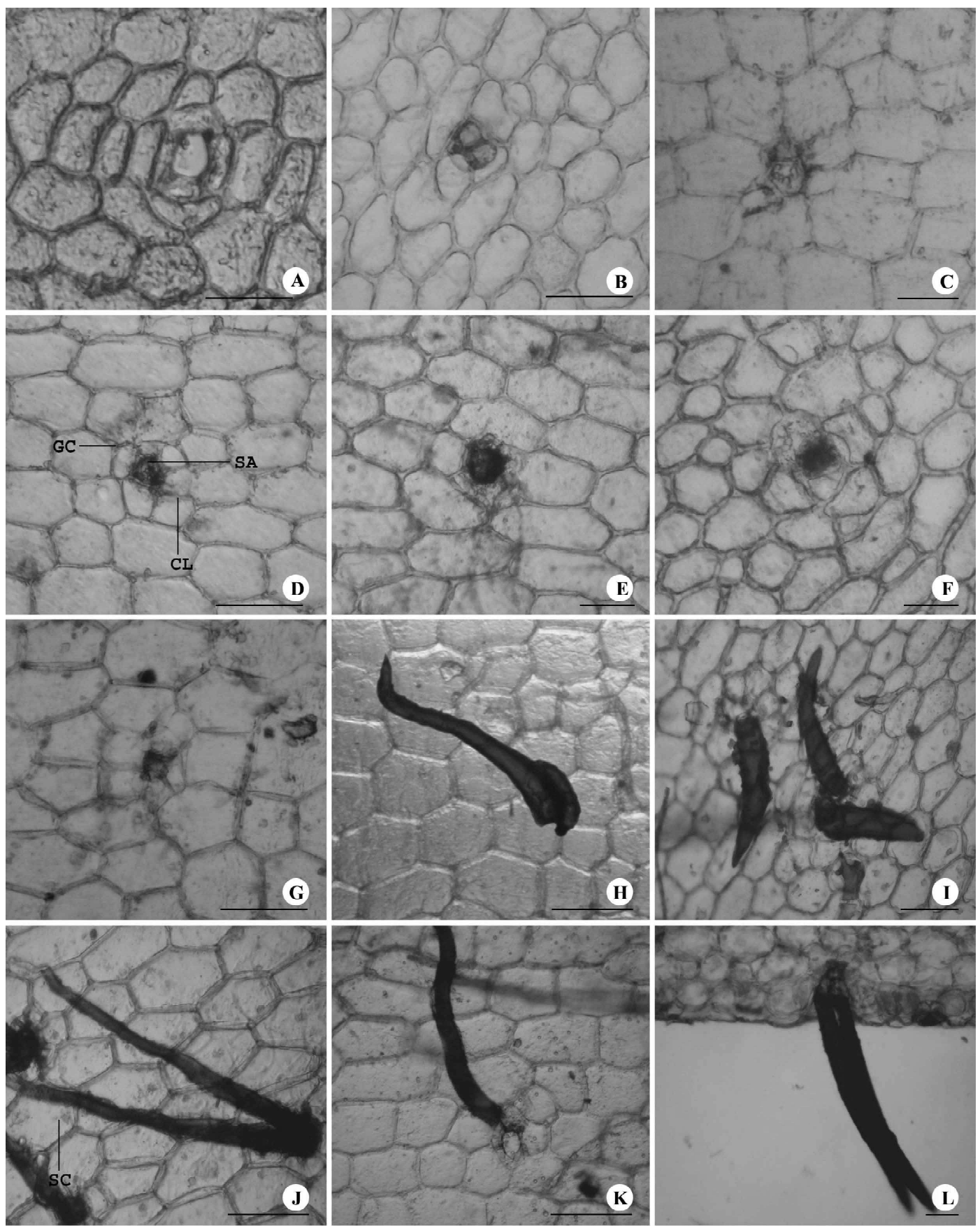

Figure 4. Wax secreting cells and trichomes at adaxial leaf epidermis. a. D. chrysotoxum, b. D. densiflorum, c. D. falconeri, d. D. fimbriatum, e. D. infundibulum, $\boldsymbol{f}$. D. jenkinsii, g. D. longicornu, , h. D. ochreatum, i. D. parcum, $\boldsymbol{j}$. D. spatella, $\boldsymbol{k}$. D. tamenglongense and $\boldsymbol{l}$. D. williamsonii. WSC wax secreting cell, TR trichome. Scale bars, $50 \mu \mathrm{m}$. 
Table 4. Leaf traits Dendrobium species (contd.)

[Abbreviations used: $d$ - stomatal density, $\mathrm{A}_{\mathrm{s}}$ - stomatal apparatus area, $\mathrm{WN}_{\mathrm{ad}}$ - adaxial wax secreting cells number, $\mathrm{WN}_{\mathrm{ab}}$ - abaxial wax secreting cells number, $\mathrm{TL}_{\mathrm{ad}}-$ adaxial trichome length, $\mathrm{TL}_{\mathrm{ab}}-$ abaxial trichome length. Results were presented as mean $\pm \mathrm{SE}]$

\begin{tabular}{|l|l|l|l|l|l|l|}
\hline Species & $\boldsymbol{d}\left(\mathbf{m m}^{-2}\right)$ & $\mathbf{A}_{\mathbf{s}}\left(\boldsymbol{\mu \mathbf { m } ^ { 2 }}\right)$ & $\begin{array}{l}\mathbf{W N}_{\mathbf{a d}} \\
\left(\mathbf{m m}^{-2}\right)\end{array}$ & $\begin{array}{l}\mathbf{W N}_{\mathbf{a b}} \\
\left(\mathbf{m m}^{-2}\right)\end{array}$ & $\begin{array}{l}\mathbf{T L}_{\mathbf{a d}} \\
(\boldsymbol{\mu m})\end{array}$ & $\begin{array}{l}\mathbf{T L}_{\mathbf{a b}} \\
(\boldsymbol{\mu \mathbf { m }})\end{array}$ \\
\hline D. chrysotoxum & $16.45 \pm 0.39$ & $834.2 \pm 44.6$ & $16.0 \pm 0.52$ & $58.60 \pm 0.84$ & - & - \\
\hline D. densiflorum & $12.20 \pm 0.33$ & $805.9 \pm 38.4$ & $14.7 \pm 0.7$ & $37.2 \pm 1.62$ & - & - \\
\hline D. falconeri & $14.7 \pm 0.44$ & $740.3 \pm 23.5$ & $42.3 \pm 1.85$ & $33.9 \pm 1.18$ & - & - \\
\hline D. fimbriatum & $7.02 \pm 0.17$ & $912.8 \pm 56.8$ & $16.80 \pm 0.48$ & $40.5 \pm 1.20$ & - & - \\
\hline D. infundibulum & $9.32 \pm 0.13$ & $1511.3 \pm 44.9$ & - & - & $471.3 \pm 61.0$ & $768.8 \pm 72.3$ \\
\hline D. jenkinsii & $11.55 \pm 0.18$ & $639.9 \pm 23.2$ & $31.20 \pm 1.01$ & $31.8 \pm 1.62$ & - & - \\
\hline D. longicornu & $11.28 \pm 0.18$ & $1316.5 \pm 53.1$ & - & - & $355.0 \pm 22.1$ & $281.3 \pm 12.7$ \\
\hline D. ochreatum & $12.20 \pm 0.12$ & $1378.04 \pm 36.13$ & $3.90 \pm 0.23$ & $4.40 \pm 0.27$ & - & - \\
\hline D. parcum & $15.2 \pm 0.14$ & $730.8 \pm 31.0$ & $1.40 \pm 0.24$ & $14.10 \pm 0.78$ & - & - \\
\hline D. spatella & $2.82 \pm 0.15$ & $757.41 \pm 25.55$ & $53.00 \pm 0.60$ & $29.30 \pm 0.45$ & - & - \\
\hline D. tamenglongense & $8.5 \pm 0.19$ & $1105.4 \pm 48.0$ & $15.6 \pm 0.74$ & $26.1 \pm 0.90$ & - & - \\
\hline D. williamsonii & $4.19 \pm 0.79$ & $1838.8 \pm 62.6$ & - & - & $405.0 \pm 31.4$ & $433.8 \pm 6.9$ \\
\hline
\end{tabular}

in order to prevent water loss. Thickness of cuticle plays an important role for preventing water loss from the lamina (Bargel et al. 2004; Mill \& Stark 2009). The presence of thick cuticle on the leaf surface is an indicator of arid habitats for the plants (Haworth \& McElwain 2008). The thick cuticle layers on $D$. chrysotoxum, D. infundibulum, D. jenkinsii and $D$. williamsonii leaves can reduce rate of transpiration and increase water use efficiency during scarcity of water.

Large epidermal cells in many species of orchids serve as water-storage cells. Olantunji and Nengim (1980) have called these water storage cells as tracheoidal elements. Such club-shaped and columnar water storage cells mainly present in the leaf and run parallel to the length of the organ, which suggest the formation of a dispersed water conducting system unlike continuous vascular system. These may be helpful for imbibition of water during favourable conditions to ensure a luxuriant growth and survival of species.

Stomatal distribution, size, density and morphology are closely associated with plant transpiration (Willmer \& Fricker 1996). Larger stomata have a greater potential for hydraulic dysfunction under drought conditions (Aasamaa et al. 2001). Plants with lower stomatal density are usually able to tolerate a more arid environment than plants with higher stomatal density (Kebede et al. 1994). Generally, the stomatal density of orchid leaves is low in the entire plant kingdom (Karasawa \& Saito 1982; Willmer \& Fricker 1996). In the present study, D. spatella with its least stomatal density and $D$. jenkinsii with its small stomatal apparatus area appear to be more tolerant to the arid environment. Though, $D$. williamsonii has large stomatal apparatus area, it has minimum stomatal density next to $D$. spatella to minimize the higher rate of transpiration.

Wax secreting cells act as a protective against sunlight. They also aid in shedding rain so that the leaf cells do not become over saturated with water (Ferry 2008). In this study, $D$. spatella had maximum numbers of adaxial wax secreting cells which may protect the species from high intensity of sunlight and regulate the inner water content during heavy rain fall.

Trichomes can be protective against sun or herbivores and may help in air circulation by increasing turbulence (Yukawa et al. 1990). They also help in absorbing water in 
Bromeliaceae and in orchids (Pleurothallidinae) (Pridgeon \& Stearn 1982). In the present study, the trichomes observed in D. infundibulum, D. longicornu and D. williamsonii may probably help in absorbing water during the rainy season which is stored and consumed during subsequent dry winter period.

\section{Acknowledgements}

Authors are thankful to the Head, Department of Life Science \& Bioinformatics, Assam University, Silchar for facilities. First author is indebted to Mr. H. Kipgen, President (FEEDS $\&$ KVK, Hengbung) and the Department of Science and Technology, Government of India, New Delhi for facilities, encouragement and financial support.

\section{LITERATURE CITED}

Aasamaa, K.; Sober, A. \& Rahi, M. 2001. Leaf anatomical characteristics associated with shoot hydraulic conductance, stomatal conductance and stomatal sensitivity to changes of leaf water status in temperate deciduous trees. Aust. J. Pl. Phys. 28: $765-774$.

Bargel, H.; Barthlott, W.; Koch, K.; Schreiber, L. \& Neinhuis, C. 2004. Plant cuticles: multifunctional interface between plant and environment. In: Hemsly AR, Poole I (eds) The evolution of plant physiology, Academic Press, London. Pp. $171-194$.

Brieger, F.; Butzin, F. \& Senghas, K. 1970-1995. In F, G. Brieger, R. Maatsch, and K, Senghas (eds), Rudolph Schlechter. Die Orchideen. $3^{\text {rd }}$ ed. Vol. I, pts, Paul Parey, Berlin.

Burns-Balogh, P. \& Funk, V. 1986. A phylogenetic analysis of the Orchidaceae. Smithsonian Contributions to Botany. 61.

Chowdhery, H. J. 2009. Orchid diversity of India. J. Orch. Soc. 23(1-2): $19-42$.

Dressler, R. L. 1981. The orchids: natural history and classification. Harvard University Press, Cambridge. MA.

Dressler, R. L. 1993. Phylogeny and classification of the orchid family. Timber Press. Portland.

Dressler, R. L. \& Dodson, C. H. 1960. Classification and phylogeny in the Orchidaceae. Annals of the Missouri Botanical Garden. 47: 25 - 68.

Dunbar-Co, S.; Sporck, M. J. \& Sack, L. 2009. Leaf trait diversification and design in seven rare taxa of the Hawaiian Plantago radiation. Int. J. Plant Sci. 170: $61-75$.

Ferry, R. J. 2008. Stomata, subsidiary cells and implications. Northern American Native Orchid J. 14(2): $168-174$.

Freudenstein, J. V. \& Rasmussen, F. N. 1999. What does morphology tell us about orchid relationship? - A cladistic analysis. American J. Bot. 86(2): 225 - 248.

Garay, L. A. 1960. On the origin of the Orchidaceae. Botanical Museum Leaflets 19: 57 -95 .

Garay, L. A. 1972. On the origin of the Orchidaceae, II. J. Arnold Arboretum. 53: $202-$ 215.

Govaerts, R.; Bernet, P.; Kratochvil, K.; Gerlach, G.; Carr, G.; Alrich, P.; Pridgeon, A. M.; Pfahl, J.; Campacci, M. A.; Holland Baptista, D.; Tigges, H.; Shaw, J.; Cribb, P.; Alex George; Kreuz, K. \& J. Wood. 2018. World checklist of Orchidaceae. Facilitated by the Royal Botanic Gardens, Kew. Available from: http:// www.wcsp.science.kew.org/ (accessed 07.10. 2018). 
Guan, Z. J.; Zhang, S. B.; Guan, K. Y.; Li, S. Y. \& Hu, H. 2010. Leaf anatomical structures of Paphiopedilum and Cypripedium and their adaptive significance. J. Plant Res. 124: 289 - 298. doi: 10.1007/s10265-010-0372-z.

Haworth, M. \& McElwain, J. 2008. Hot, dry, wet, cold or toxic? Revisiting the ecological significance of leaf and cuticular micromorphology. Paleogeogr Palaeoclimatol Paleoecol. 262: 79 - 90.

Karasawa, K. \& Saito, K. 1982. A revision of the genus Paphiopededilum (Orchidaceae). Bull. Hiroshima Bot. Gard. 5: $1-69$.

Kebede, H.; Martin, B.; James, N. \& Gretchen, K. 1994. Leaf anatomy of two Lycopersicon species with contrasting gas exchange properties. Crop. Sci. 34: $108-113$.

Khuiraijam, S. J. \& Roy, R. P. 2016. Dendrobium kentrophyllum (Orchidaceae) - a new record for the orchid flora of Manipur, India. Richardiana. 16: 273 - 276.

Kishor, R. K.; Nanda, Y.; Sharma, H. B.; Jennifer, T. \& Vij, S.P. 2013. Dendrobium tamenglongense sp. nov. (Orchidaceae) from Manipur, India. Nordic J. Bot. 32(2): 150-153. http://dx.doi.org/10.1111/j.1756-1051.2013.00124.x.

Kumar, C. S. \& Kumar, P. C. S. 2005. An Orchid Digest of Manipur, North Eastern India. Rheedea. 15(1): $1-70$.

Meitei, L. R.; Rabha, N. N.; Chaya Deori. \& A. A. Mao. 2014. A new generic record and distribution notes on two orchids species from Manipur, India. Richardiana. 14: 274 -279 .

Mill, R. R. \& Stark, S. D. M. 2009. Cuticle micromorphology of Saxegothaea (Podocarpaceae). Bot. J. Linn. Soc. 159: $58-67$.

Misra, S. 2007. Orchids of India - A glimpse. Binshen Singh Mahendra Pal Singh, Dehra Dun, India. Pp. 279 - 320.

Nanda, Y.; Sharma, H. B.; Kishor, R. K.; Rao, A. N. \& Vij, S.P. 2012. Dendrobium bicameratum Lindley (Orchidaceae) - an addition to the flora of Manipur, India. Pleione. 6(2): $450-452$.

Nanda, Y.; Chowlu, K.; Sharma, H. B.; Rao, A. N. \& Vij, S.P. 2013. Four new records of Dendrobium Sw. (Orchidaceae) to Manipur (India). Nelumbo. 55: 1 - 7.

Nanda, Y.; Chowlu, K.; Rao, A. N. \& Vij, S. P. 2014. Dendrobium sinuminutiflorum S.C. Chen, J. J. Wood \& H. P. Wood (Orchidaceae) - a new record for India from Manipur. Pleione 8(1): $167-170$.

Olatunji, O. A. \& Nengim, R. O. 1982. Occurrence and distribution of tracheiodal elements in the Orchidaceae. Bot. J. Linn. Soc. 80: $357-370$.

Pandey, S. K.; Singh, H. \& Singh, J. S. 2009. Species and site effects on leaf traits of woody vegetation in a dry tropical environment. Current Sci. 96: 1109- 1114.

Pridgeon, A. M. \& Stern, W. L. 1982. Vegetative anatomy of Myoxanthus (Orchidaceae). Selbyana. 7: $55-63$.

Rao, A.N. 2007. Orchid Flora of North East India - An Upto Date Analysis. Bull. Arunachal Forest Res. Vol. 23 (1 \& 2): 6 - 38.

Rasmussen, F. N. 1985. Orchids. In R. M. T. Dahlgren, H. T. Clifford, and P.F. Yeo (eds). The families of the monocotyledons, Springer-Verlag. Berlin. Pp. $294-274$.

Szlachetko, D. L. 1995. Sytema Orchidalium. Fragmenta Floristica et Geobotanica Supplementum 3: 1-152. 
Hidangmayum Bishwajit Sharma \& Debjyoti Bhattacharyya 121

Vendramini, F.; Diaz, S.; Gurvich, D. E.; Wilson, P. J.; Thompson, K. \& Hodgson, J. G. 2002. Leaf traits as indicators of resource-use strategy in floras with succulent species. New Phytol 154: 147-157.

Vermeulen, P. 1966. The system of the Orchidales. Acta Botanica Neerlandica 15: $224-$ 253.

Willmer, C. \& Fricker, M. 1996. Stomata, topics in plant functional biology, $2^{\text {nd }}$ edn. Chapman and Hall. London.

Wood, H.P. 2006. The Dendrobiums A. R. G. Ganter Verlag, Ruggell/ Liechtenstein, Pp. $29-52$.

Yukawa, T.; Ando, K. \& Hashimoto, K. 1990. Leaf surface morphology in selected Dendrobium species. Proceeding of the $13^{\text {th }}$ World Orchid Conference. Auckland, New Zealand. Pp. $250-258$. 